\title{
PERAN PEMERINTAH DAERAH DALAM PENGEMBANGAN OBJEK WISATA DI PULAU BOKORI KABUPATEN KONAWE
}

\author{
Nurjannah $^{1}$
}

\section{${ }^{1}$ Alumni Jurusan Pendidikan Geografi FKIP UHO}

\begin{abstract}
Abstrak: Rumusan masalah dalam penelitian ini 1) Bagaimana Peran Pemerintah Daerah Dalam Pengembangan Objek Wisata di Pulau Bokori Kebupaten Konawe? dan 2). Kendala-kendala dalam pengembangan objek wisata di Pulau Bokori Kabupaten Konawe?.Penelitian ini menggunakan metode penelitian deskriptif kualitatif dan teknik pengumpulan data yang di gunakan adalah teknik observasi, wawancara dan studi dokumentasi. Hasil penelitian menujukan bahwa Peran Pemerintah Daerah Dalam Pengembangan Objek Wisata di Pulau Bokori Kebupaten Konawe sebagai motivator, Pemeintah Daerah mengoptimalkan pelaksanaan atraksi wisata pada objek wisata di pulau Bokori seperti kondisi tanah dan pemandangan, floran dan fauna, keadaan alam dan festival atau evebt-event daerah misalnya kegiatan voli pantai tingkat nasional. Sebagai fasilitator, Pemerintah Daerah sudah membangun fasilitas-fasilitas yang di butuhkan dalam perkembangan objek wisata di Pulau Bokori seperti pembangunan villa, penyediaan air, dan hiburan. Dinamisator, Pemerintah Daerah mengsinergikan pihakpihak dinas lain dan masyarakat dalam proses pengembangan objek wisata di pulau Bokori. kendala-kendala dalam pengembangan objek wisata di pulau Bokori adalah rendahnya kesadaran masyarakat akan pentingnya manfaat pariwisata.
\end{abstract}

Kata Kunci : Peran, Pemerintah Daerah, Proses, Pengembangan, Objek Wisata 


\title{
THE ROLE OF LOCAL GOVERNMENTS IN THE DEVELOPMENT OF A TOURISM OBJECT IN THE KONAWE DISTRICT, BOKORI ISLAND
}

\section{Nurjannah $^{1}$}

\section{${ }^{1}$ Alumni Of Geography Education FKIP UHO}

\begin{abstract}
Research problem in this study were: 1). What is the role of local governments in the development of tourism objects in Konawe Regency on Bokori Island, and 2) What are constraints in the development of tourist objects on the island of Bokori, Regency Konawe? This study used descriptive methods of qualitative research and technique of the data collection used observation, interview and study of documentation. The result showed that the role of local governments in the development of Konawe regency tourism objects on Bokori Island was a motivating factor, The regional government optimizes the implementation of tourist attractions on Bokori Island attractions such as the conditions of the land and landscapes, flora and fauna, natural conditions and festivals such as national beach volleyball activities. As a facilitator, the regional government built the necessary facilities for the development of tourism objects on the island of Bokori, such as villa construction, water supply and entertainment. Dynamization, the regional government synergizes other service agencies and the community in the process of developing tourist objects on the island of Bokori. The constraints in the development of tourist attractions on the island of Bokori were a low awareness of the importance of the benefits of tourism
\end{abstract}

Kata Kunci: Role, Local Government, Process, Development, Tourism Object

\section{PENDAHULUAN}

Sektor pariwisata merupakan salah satu sektor yang sangat strategis bagi perekonomian suatu daerah, terutama dalam meningkatkan pendapatan masyaarakat akat, pendapatan asli daerah dan devisa negara. Pariwisata dapat memberikan banyak manfaat sosial, ekonomi bahkan penunjang pembangunan di lingkungan hidup, selain itu pariwisata juga kerap dijadikan langkah awal yang dilakukan untuk memajukan perekonomian suatu negara. Dunia kepariwisataan sekarang ini dapat dirasakan semakin bertambah pesat dari tahun ke tahun dan menjadi sektor yang sangat strategis bagi setiap Negara untuk menambah devisa negara dari sektor non migas. maka program pengembangan dan pemanfaatan sumber 
daya dan potensi pariwisata daerah diharapkan dapat memberikan sumbangan bagi pembangunan ekonomi.

Dalam pengembangan pariwisata perlu di dukung elemen-elemen penting dalam kepariwisataan harus melaksanakan fungsinya dengan melakukan perencanaan dan pelaksanaan yang maksimal.Pemerintah pusat, pemerintah provinsi, pemerintah kabupaten/kota memiliki kewenangan guna mewujudkan kepariwisataan yang sesuai dengan kebijakan. Dalam penjelasan UU No. 10 tahun 2009 tentang kepariwisataan pasal 23 poin $\mathrm{c}$ menyatakan " memelihara, mengembangkan dan melestarikan asset nasional yang menjadikan daya tarik wisata dan asset potensial yang belum tergali".

Provinsi Sulawesi Tenggara memiliki banyak lokasi potensial yang dijadikan atau dikembangkan sebagai obyek wisata.Sulawesi Tenggara menyimpan begitu banyak wisata pantai atau bahari yang tidak kalah dengan daerah lainnya di nusantara. Salah satu pesona wisata yang ditawarkan Sulawesi Tenggara adalah Pulau Bokori.

Pulau Bokori sebelumnya sudah pernah berkembang menjadi objek wisata pada masa pemeritahan La Ode Kaimoeddin, objek wisata ini sempat jaya sebagai salah satu objek wisata bahari andalan Sulawesi Tenggara. Berbagai pohon tumbuh di Pulau Bokori, pemerintah juga membangun puluhan cottage di sepanjang bibir pantai, bahkan rumah permanen dua lantai berdiri kokoh disana, masyarakat setempat menyebutnya sebagai rumah jabatan (rujab) gubernur. Kemudian setelah wafatnya pengelola atau orang dipercayakan untuk menjaga Pulau Bokori, tidak ada lagi masyarakat yang bertanggung jawab memelihara objek wisata ini. Saat itulah masyarakat yang tidak bertanggung jawab mulai merambah Pulau Bokori. Pasir, batu karang, pepohonan, papan, kayu-kayu dan satu persatu cottage tersisa tiggal tiang saja semuanya tidak luput dari tangan-tangan jahil.Abrasi semakin tak terkendali karena pasir dan batu karang yang terus dieksploitasi. Sejak saat itu pula, Pulau Bokori sudah tidak terdengar lagi, seiring berjalannya waktu namanya kian tenggelam. Apalagi setelah pemerintah Kabupaten Konawe membuka objek wisata Pantai Toronipa. Setelah sekian lama tidak ada aktivitas di Pulau Bokori pemerintah propinsi Sulawesi Tenggara dibawah pimpinan Gubernur Sulawesi Tenggara Nur Alam kembali menjadikan pulau Bokori sebagai destinasi wisata andalan Sulawesi Tenggara. Pulau Bokori kemudian di kelola kembali agar Pulau Bokori cantik seperti sedia kala.Cottage mulai dibangun kembali, begitupun dengan jalan setapak, pasir mulai di timbun, sarana dan parasara lainnya mulai dibangun serta fasilitas yang dapat menunjang pengembangan objek wisata ini di bangun.

Pulau Bokori memiliki objek dan daya tarik wisata yang indah misalnya pemandangan yang asri, suasan yang 
tenang ,pasir putih yang halus dan bersih, dengan ombak yang teratur, hembusan angin yang sejuk, pohonpohon kelapa yang berjejer, adanya vilavila yang di sewakan sebagai tempat istrahat dan perairannya bening memantulkan warna biru di kedalaman dan putih dikedangkalan, selain keindahan alam letak Pulau Bokori yang tidak jauh dari Kota Kendari memberikan satu lagi keunggulan dari pulau ini. Dimana untuk menjangkau pulau ini bisa dilakukan dalam waktu 30 menit dari kota Kendari bisa menggunakan roda dua atau roda empat, kemudian menyebrang mengunakan kapal dari Desa Bajo Kecamatan Soropia dengan waktu 5-10 menit. Pulau Bokori memiliki potensi untuk dijadikan tujuan wisata.

Namun objek wisata Pulau Bokori dapat dikatakan belum dikembangkan secara optimal hal tersebut dapat dilihat dari gejala-gejala masalah yang ada di wisata tersebut seperti: Minimnya pengadaan restauran atau warung makan, dimana keberadaaan sarana ini sangat dibutuhkan dalam dunia pariwisata dan bisa menjadi daya tarik dari suatu objek wisata bila dilestarikan dengan baik, wisata Pulau Bokori juga Belum nampak seni dan budaya dengan mempertahankan kondisi keanekaragaman parawisata seperti atraksi budaya yang berwawasan alam, kerajianan, serta adat istiadat guna meningkatkan jumlah wisatawan. minimnya pengadaan fasilitas rekreasi seperti jet ski, alat-alat diving bagi wisatawan yang ingin menyelam, dan lain sebagainya, sehingga dengan di sediakan fasilitas rekreasi yang beraneka ragam dapat menarik minat wisatawan untuk berkunjung di daerah wisata, Kelestarian alam yang perlu dipertahankan, menampilkan atraksi wisata baik potensi yang sudah ada maupun hasil ciptaan manusia, belum adanya program asuransi bagi pengunjung di Pulau Bokori, hal ini diperlukan karena dalam mengakses untuk sampa di tempat wisata pulau Bokori pengujung atau wisatawan harus menyebrang laut dengan menggunakan kapal dan tidak menuutup kemungkinan jika terjadi hal-hal yang tidak diinginkan maka hendaknya pihak pengelolah mengadakan program asuransi kesehatan bagi pengunjung.

Pemerintah daerah memiliki peran untuk mengembangkan potensi pariwisata daerahnya sebagai berikut:

a. Motivator, dalam pengembangan pariwisata, peran pemerintah daerah sebagai motivator diperlukan agar geliat usaha pariwisata terus berjalan.

b. Fasilitator, sebagai pemfasilitas pengembangan potensi pariwisata peran pemerintah adalah menyediakan segala fasilitas yang mendukung segala program yang diadakan oleh pemerintah daerah.

c. Dinamisator, agar dapat berlansung pembangunan yang ideal, maka pemerintah, swasta dan masyarakat harus dapat bersinergi dengan baik. Pemerintah daerah sebagai salah satu stakeholder pembangunan pariwisata 
memiliki peran untuk mensinergiskan ketiga pihak tersebut, agar diantaranya tercipta suatu simbiosis mutualisme demi perkembangan pariwisata. (Pitana dan Gayatri dalam Muis A. 2016:3991).

\section{METODE PENELITIAN}

\section{a. Lokasi Penelitian}

Penelitian ini dilakukan di Dinas Pariwisata Provinsi Sulawesi Tenggara, dengan pertimbangan Dinas ini merupakan Dinas yang mengelola objek wisata di Pulau Bokori dan di lokasi objek wisata di Pulau Bokori.

\section{b. Informan Penelitian}

Penentuan informan penelitian yang dilakukan peneliti menggunakan teknik purposive sampling yaitu teknik penentuan sampel dengan pertimbangan atau kriteria-kriteria tertentu. Dalam sebuah penelitian diperlukan orangorang yang akan peneliti pilih sebagai pemberi informasi mengenai data yang diperlukan. Dalam penelitian ini informan berjumlah 15 orang yaitu 4 orang pemerintah daerah yakni Dinas Provinsi Sulawesi Tenggara, dan 5 orang masyarakat di sekitar Pulau Bokori dan 6 orang pengunjung di Pulau Bokori.

\section{c. Jenis dan Sumber Data}

1. Jenis data

Adapun data dalam penelitian ini yaitu data kualitatif dan kuantitatif.

a. Data kualitatif yaitu yang disajikan dalam bentuk kata verbal yang termaksuk data kualitatif dalam penelitiaan ini adalah bagaimana pengembangan objek wisata pulau Bokori.

b. Data kuantitatif adalah jenis data yang dapat di ukur secara langsung yang berupa informasi yang dinyatakan dalam bilangan atau angka. Dalam hal ini data kuantitatif yang diperlukan adalah jumlah pengurus pemerintah daerah terkhusus di Dinas Pariwisata Kabupaten Konawe, truktur organisasi, saran dan prasaran dan data-data yang diperlukan dalam penelitian.

2. Sumber data

Data yang di kumpulkan dalam penelitian ini adalah sebagai berikut:

a. Data primer

Data Primer, yaitu berupa kata-kata dan tindakan yang bersumber dari informan serta peristiwa-peristiwa tertentu yang berkaitan dengan fokus penelitian dan merupakan hasil pengumpulan peneliti sendiri selama berada di lokasi penelitian.

b. Data sekunder

Data sekunder merupakan sumber yang tidak langsung memberikan data kepada pengumpul data, misalnya lewat orang lain atau melalui dokumen. Data Sekunder, yaitu data-data tertulis yang digunakan sebagai informasi pendukung dalam analisis data primer.Data ini pada umumnya berupa dokumen-dokumen tertulis yang terkait dengan Peran Pemerintah Daerah Dalam 
Pengembangan Objek Wisata Pulau Bokori.

\section{d. Tehnik Pengumpulan Data}

Teknik pengumpulan data yang digunakan dalam penelitian ini adalah melalui wawancarara, observasi, dan dokumentasi, secara singkat dijelaskan bahwa tekhnik pengumpulan data dalam penelitian ini sebagai berikut:

a. Wawancara terstruktur

Wawancara terstruktur digunakan sebagai teknik pengumpulan data, bila peneliti atau pengumpul data telah mengetahui dengan pasti tentang informasi apa yang akan diperoleh. Oleh karena itu dalam melakukan wawancara, pemgumpul data telah menyiapkan instrument penelitian berupa pertanyaan-pertanyaan tertulis yang alternative jawabannya telah disiapkan.

Dalam Penelitian ini, peneliti mendatangi langsung informan untuk mendapatkan informasi terkait fokus penelitian.Wawancara dilakukan secara mendalam guna mendapatkan informasi terkait peran pemerintah daerah dalam pengembangan objek wisata di Pulau Bokori.Peneliti mendatangi langsung informan untuk melakukan wawancara secara langsung kepada informan-informan terkait.

\section{b. Observasi}

Observasi merupakan proses suatu yang kompleks, suatu proses yang tersusun dari berbagai proses yang biologis dan psikologis. Observasi juga merupakan peninjauan terhadap lokasi penelitian untuk mendapatkan gambaran yang terjadi di lapangan. Observasi atau pengamatan langsung dilakukan dengan cara, peneliti secara langsung berkunjung dan beraktivitas di objek wisata Pulau Bokori dengan cara berkeliling, mengamati dan mendokumentasikan area wisata Pulau Bokori sehingga peneliti dapat memberikan gambaran yang jelas mengenai kondisi objek yang sedang diteliti.

\section{c. Dokumentasi}

Dalam penelitian ini, dokumen yang disajikan berupa informasi informasi terkait yang dibutuhkan dan digunakan pada hasil dan pembahasan nantinya, untuk memperkuat, mendasari sebuah pemikiran, atau membuktikan deskripsi yang penulis sampaikan. Dokumen diperoleh dari Dinas Pariwisata Provinsi Sulawesi Tenggara serta dokumen lainnya berupa lampiran skripsi, melalui peraturan dan kebijakan atau peraturan terkait, transkip wawancara, dan fotofoto dokumentasi terkait objek yang diteliti.

\section{e. Teknik Analisa Data}

Data yang di peroleh melalui hasil wawancaradi dokumen dan bahanbahan lainnya, kemudian di analisis menggunakan model analisis deskriptif kualitatif. Sebelum data hasil penelitian dianalisis data di olah dengan teknik editing, tabulasi data, dan interpretasi untuk mempermudah analisis data kualitatif. Oleh karena itu, pengolahan data dilakukan dengan cara menggolongkan data berdasarkan sifat 
dan jenisnya, selain itu proses pengolahan data juga dilakukan dengan skoring dan tabulasi. Untuk mendapatkan presentase dari setiap frekuensi jawaban informan di gunakan rumus:

$$
P=\frac{F}{N} \times 100 \%
$$

Keterangan:

$\mathrm{P}=$ Persentase pilihan.

$\mathrm{F}=$ Frekuensi (jumlah informan yang memilih alternatif yang sama).

$\mathrm{N}=$ Jumlah informan keseluruhan.

$100=$ Persentase $(\%)$

\section{Teknik editing}

Dalam penelitian ini dilakukan dengan cara menyalin ulang hasil wawancara dengan informan yang merupakan data mentah berupa catatan peneliti yang berkaitan dengan bagaimana peran pemerintah daerah dalam pengembagan objek wisata di pulau Bokori dalam bentuk tulisan atau catatan lengkap, serta memilah data atau informasi. Tidak semua kutipan hasil wawancara, dan data yang diperoleh dari dokumen yang didapatkan peneliti peneliti cantumkan, namun hanya informasi yang diperlukan saja yang ditampilkan, sementara keterangan lengkapnya disajikan sebagai transkip wawancara atau lampiran.

\section{Interpretasi}

Interpretasi ,adalah penjelasan yang terperinci tentang arti yang sebenarnya dari materi yang dipaparkan (Nazir, dalam Lusita. 2017). Adapun proses interpretasi atas hasil penelitian ini yaitu peneliti mencoba mengartikan, mencari inti pokok, atau maksud dari informasi yang ada baik dari hasil wawancara maupun dokumen yang diperoleh.

3. Triangulasi data

Dilakukan untuk menguji kebenaran dan keabsahan data Dalam penelitian ini, peneliti menggunakan triangulasi sumber yang dilakukan dengan cara mencocokkan data yang didapat melalui teknik wawancara, observasi dan studi dokumentasi. Data yang didapat dari hasil wawancara dengan pihak Dinas Pariwisata kemudian dianalisis dan dicocokkan dengan data-data yang didapat melalui studi dokumentasi. Langkah berikutnya adalah peneliti mengkonfirmasi kebenaran data dengan cara melakukan observasi di lapangan guna memperoleh kecocokan dengan data lain. Data lain yang dimaksud adalah keterangan dari informan penelitian di lapangan yang meliputi keterangan dari masyarakat di sekitar objek wisata di Pulau Bokori, keterangan pengunjung. Melalui Triangulasi data, maka diperoleh informasi yang valid dan jelas mengenai peran pemerintah daerah dalam pengembangan objek wisata di Pulau Bokori Kabupaten Konawe.Melalui hasil triangulasi, dapat terlihat apakah rumusan masalah penelitian sudah terjawab, dan tujuan penelitian sudah tercapai. 


\section{HASIL PENELITIAN}

$\begin{aligned} & \text { Penelitian ini bertujuan } \\ & \text { mengetahui } \\ & \text { bemerintah } \\ & \text { daerah }\end{aligned}$
mengembangkan objek wisata di Pulau
Bokori Kabupaten Konawe dengan
indikator peran sebagai motivator,
fasilitator dan dinamisator.Informan
peneliatian ini sebangyak 15 orang
yang terdiri atas pegawai Dinas
Pariwisata Provinsi Sulawesi
Tenggara, masyarakat ran
wisatawan.Penentuan informan ini

menggunakan teknik purposive sampling.Penelitian dilaksanakan pada tanggal 5 juni sampai 1 juli 2018.Penelitian ini menggunakan metode deskiptif kualitatif untuk mengetahui tentang pengembangan objek wisata yang ada di Pulau Bokori.

1. Pengetahuan tentang atraksi wisata di objek wisata di Pulau Bokori

Table 3.1. Terdapat atraksi wisata objek wisata di Pulau Bokori

\begin{tabular}{lccc}
\multicolumn{1}{c}{ Variabel } & Frekuensi & Persentase \\
\hline a. & Ya & 15 & $100 \%$ \\
\hline b. & Tidak & 0 & \\
\hline \multicolumn{2}{c}{ Jumlah } & 15 & $100 \%$
\end{tabular}

\section{Sumber: Diolah dari hasil wawancara 2018}

Berdasarkan tabel di atas menunjukan keseluruhan responden sudah pernah diadakan di objek mengatakan bahwa atraksi wisata wisata di Pulau Bokori.

Tabel 3.2 Atraksi wisata yang ada di Pulau Bokori Variable Frekuensi Persentase

\begin{tabular}{llcc}
\hline a. & Flora dan fauna & 3 & 20 \\
\hline $\begin{array}{l}\text { b. } \\
\begin{array}{l}\text { Bentuk tanah dan } \\
\text { pemandangan }\end{array}\end{array}$ & 7 & $\mathbf{4 6 , 6 \%}$ \\
\hline c. & Keadaan alam & 5 & $33,3 \%$ \\
\hline d. Agama & & \\
\hline & Jumlah & 15 & $100 \%$ \\
\hline
\end{tabular}

Sumber: diolah dari hasil wawancara 2018

Berdasarkan tabel di atas 46,6\%, urutan kedua keadaan alam menunjukan dari 15 orang responden, terdapat 5 orang atau 33,3\% dan maka urutan pertama bentuk tanah dan urutan terakhir Flora dan fauna pemandangan terdapat 7 orang atau terdapat 3 orang atau $20 \%$. Maka 
dengan demikian dari data di atas dapat di simpulkan bahwa atraksi wisata di objek wisata di pulau Bokori sudah ada dan jenis atraksinya berupa bentuk tanah dan pemandangan, keadaan alam dan flora dan fauna.

2. Pengetahuan tentang fasilitas objek wisata di pulau Bokori

Tabel 3.3. Fasilitas objek wisata di pulau bokori sudah bagus

\begin{tabular}{lcc} 
Variabel & Frekuensi & Persentase \\
\hline a. Ya & 15 & $100 \%$ \\
\hline b. Tidak & 0 & \\
\hline Jumlah & 15 & $100 \%$
\end{tabular}

Sumber: diolah dari hasil wawancara 2018

Berdasarkan tabel di atas ada di objek wisata di Pulau Bokori menunjukan bahwa keseluruhan sudah bagus.

responden mengatakan fasilitas yang

Tabel 3.4 fasilitas objek wisata di Pulau Bokori

\begin{tabular}{lcc}
\multicolumn{1}{c}{ Variabel } & Frekuensi & Persentase \\
\hline a. Hotel dan Villa & 4 & $26,6 \%$ \\
\hline b. Restoran & 2 & $13,3 \%$ \\
\hline c. air bersih & 6 & $40 \%$ \\
\hline d. hiburan & 3 & $20 \%$ \\
\hline \multicolumn{1}{c}{ Jumlah } & 15 & $100 \%$
\end{tabular}

Sumber: diolah dari hasil wawancara 2018

Berdasarkan tabel di atas dapat menujukan bahwa dari 15 orang responden, maka air bersih berada pada urutan pertama terdapat 6 orang atau $40 \%$, kemudian urutan kedua Villa terdapat 4 orang atau $26,6 \%$, kemudian urutan ketiga hiburan terdapat 3 orang atau $20 \%$, dan urutan terakhir restoran terdapat 2 orang atau $13,3 \%$. Demikian data di atas menunjukan bahwa dari aspek fasilitas objek wisata di Pulau Bokori sudah memadai.

3. Pengetahuan tentang kerja sama pemerintah daerah dengan pihak-pihak.

Tabel 3.5. Kerja sama pemerintah daerah dengan pihak lain

\begin{tabular}{|c|c|c|}
\hline Variabel & Frekuensi & Persentase \\
\hline a. Swasta & $\mathbf{0}$ & \\
\hline b. Dinas lain & 4 & $26,6 \%$ \\
\hline c. masyarakat & 11 & $73.3 \%$ \\
\hline investor & $\mathbf{0}$ & \\
\hline Jumlah & $\overline{15}$ & $100 \%$ \\
\hline
\end{tabular}

Sumber: diolah dari hasil wawancara 2018 
Berdasarkan tabel di atas orang atau 26,6. Jadi dapat di jelaskan menunjukan dari 15 responden. Maka bahwa pemerintah daerah menjalin masyarakat menduduki urutan pertama kerja sama dengan pihak dinas lain dan terdapat 11 orang atau $73,3 \%$ dan urutan kedua dinas lain terdapat 4

masyarakat.

Tabel 3.6. Bentuk kerja sama pemerintah daerah dengan pihak lain

\begin{tabular}{lcc}
\multicolumn{1}{c}{ Variabel } & Frekuensi & Persentase \\
\hline a. investasi modal & 0 & \\
\hline b. kebersihan & 4 & $26,6 \%$ \\
\hline c. keamanan & 5 & $33,3 \%$ \\
\hline d. pembanguan fisik & 6 & $40 \%$ \\
\hline \multicolumn{1}{c}{ Jumlah } & 15 & $100 \%$
\end{tabular}

Sumber: diolah dari hasil wawancara 2018

Berdasarkan tabel di atas 5 orang atau 33,3\% dan urutan ketiga menunjukan bahwa dari 15 responden, pada bidang kebersihan terdapat 4 orang maka pemerintah daerah dalam hal menjalin kerja sama dengan pihak dinas lain dan masyarakat menunjukan bidang pembangunan fisik menduduki urutan pertama terdapat 6 orang atau $40 \%$, atau $26,6 \%$.

4. Kendala-kendala dalam pengembangan objek wisata di Pulau Bokori Kabupaten Konawe. bidang keamanan urutan kedua terdapat

Tabel 3.7. Kendala apa saja dalam pengembangan objek wisata di Pulau Bokori

\begin{tabular}{|lcc|}
\hline \multicolumn{1}{|c|}{ Variabel } & Frekuensi & Presentase \\
\hline a. Rendahnya kesadaran masyarakat & 15 & $100 \%$ \\
\hline b. Kurangnya modal & 0 & \\
\hline c. Pengelola pariwisata bersifat Top-down & 0 & \\
\hline d. Sistem transportasi & 0 & $100 \%$ \\
\hline Jumlah & 15 & 15 \\
\hline
\end{tabular}

Sumber: data diolah dari hasil wawancara 2018

Berdasarkan tabel di atas menunjukan bahwa keseluruhan responden mengatakan bahwa yang menjadi kendala dalam pengembangan objek wisata di pulau Bokori adalah rendahnya kesadaran masyarakat.

\section{PEMBAHASAN}

Peran pemerinntah daerah dalam pengembangan objek wisata di pulau Bokori

a. Peran motivator

Berdasarkan hasil penelitian yang di lakukan di Dinas Pariwisata Provinsi 
Sulawesi Tenggara dan di kawasan objek wisata di Pulau Bokori peneliti mendapatkan informasi dan data mengenai peran pemerintah sebagai motivator dalam mengebangkan objek wisata di Pulau Bokori sudah cukup maksimal di tandai dengan adannya atraksi wisata dan promosi pariwisata. Atraksi wisata yang ada di objek wisata di Pulau Bokori seperti keadaan alam diman di Pulau Bokori memiliki udara yang sejuk, bentuk tanah dan pemandangan yang dimana objek wisata di Pulau Bokori memiliki pasir yang putih, keadaan laut yang jernih dan biru, flora dan fauna dimana objek wisata di Pulau Bokori memiliki flora dan fauna beragam, flora dan fauna di objek wisata di Pulau Bokori saat ini masih dalam tahap pelestarian seperti penanaman mangrove dan penanaman terumbu karang dan sebagainya.

b. Peran fasilitator

Dari penelitian ini di dapatkan informasi atau data bahwa peran pemerintah daerah sebagai fasilitator adalah memfasilitasi aspek aspek yang berhubungan dengan pengebangan objek wisata di Pulau Bokori, adapaun fasilitas yang telah dibangun di objek wisata di Pulau Bokori diantaranya adalah villa, kazebo, penyedian air bersih, hiburan, restoran, toilet, jaminan kesehatan dan aksebilitas berupa jalan dan jembatan serta panggung yang saat ini sementara dibangun, jembata dan pembuatan tulisan I Love Bokori . Hal ini dapat dilihat bahwa dalam pengembangan objek wisata di Pulau Bokori,
Kabupaten Konawe pemerintah daerah dalam menjalankan perannya sebagai fasilitator sudah hampir mencapai target maksimal walaupun masih ada bebepa fasilitas yang sampai saat ini belum disediakan yang salah satunya adalah penambahan alat rekreasi atau wahana bermain seperti jat skill di Pulau Bokori, Kabupaten Konawe

c. Peran dinamisator

Dari penelitian ini peneliti mendapatkan informasi atau data bahwa pemerintah daerah dalam menjalankan perannya sebagai dinamisator dalam pengembangan objek wisata Di Pulau Bokori, Kabupaten Konawei sudah maksimal dilihat dalam pengembangan objek wisata di Pulau Bokori Kabupaten Konawe tidak hanya bekerja sendiri tetapi mengsinergikankan dinas/lembaga lain dan masyarakat dalam pembangunan objek wisata di Pulau Bokori, Kabupaten Konawe. Pihak dinas/lembaga lain berkerja sama dalam pariwisata adalah pembangunan jalan, dermaga penyebrangan, lampu jalan, jembatan, penanaman terumbu karang dalam laut dan sebagainya. dan masyarkat bekerjasama dalam penyedia perahu penyebrangan, penyebragan air besih menuju Pulau Bokori. tenaga kebersihan, keamana.

d. Kendala-kendala dalam pengembangan objek wisata di pulau Bokori Kabupaten Konawe.

Kendala yang di alami pemerintah daerah dalam menjalankan perannya adalah rendahnya kesadaran masyarakat tentang pentingnya pengembangan 
pariwisata.Dari penelitian ini di dapat data dan informasi mengenai kendalakendala dalam pengembangan objek pariwisata yaitu rendahnya kesadaran masyarakat tentang pentingnya pengembangan pariwisata seperti kurangnnya kesadaraanya masyarakat dalam menjaga kebersihan di sekitar objek wisata di pulau Bokori, kurangnya kesadaran masyarakat memahami tentang manfaat esensial pariwisata dalam hal ini pembuatan soufenir atau cendra mata pernak pernik khas pulau Bokori olehnya itu sebaiknya kendala ini menjadi tanggung jawab bersama antara pemerintah daerah dan masyarakat disekitar di pulau Bokori dengan mempertimbangkan aspek atau hal yang bisa menjadi pemicu kurangnya wisatawan yang berkunjung di pulau Bokori.

\section{KESIMPULAN}

1. Peran Pemerintah Daerah Dalam Pengembangan Objek Wisata di Pulau Bokori Kabupaten Konawe

a) Motivator, Peran Pemerintah Daerah dalam mengembangkan objek wisata di pulau Bokori sebagai pendorong dalam pengembangan potensi objek wisata yang ada di wisata pulau Bokori sejauh ini sudah terlaksana dengan baik dengan adanya berbagai atraksi wisata yang ada di objek wisata di Pulau Bokori.. b) Fasilitator, dalam menjalankan perannya dalam pengembangan objek wisata di Pulau Bokori Kabupaten Konawe, pemerintah paerah sudah cukup maksimal dilihat dari fasiliatas dan aksebilitas yang sudah dibangun di objek wisata di Pulau Bokori berupa villa, restoran, penyediaan air bersihm hiburan, jalan dan jembatan.

c) Dinamisator, Peran Pemerintah Daerah dalam pengembangan objek wisata di pulau Bokori Kabupaten Konawe sebagai penggerak dipastikan tidak dapat berjalan sendiri tanpa adanya kerjasama dengan pihak-pihak dinas lain maupun dukungan masyarakat. Karena sudah dipastikan pemerintah daerah tidak bisa berjalan sendiri dan bekerja sendiri untuk mengembangkan objek wisata di pulau Bokori kabupaten Konawe tanpa campur tangan pihak dinas lain dan masyarakat.

2. Kendala Pemerintah Daerah dalam pengembangan objek wisata di pulau Bokori Kabupaten Konawe adalah rendahnya kesadaran masyarakat tentang pentingnya pengembangan pariwisata seperti kurangnnya kesadaraanya masyarakat dalam menjaga kebersihan di sekitar objek wisata di pulau Bokori, kurangnya kesadaran masyarakat memahami tentang manfaat esensial pariwisata dalam hal ini pembuatan soufenir 
Jurnal Penelitian Pendidikan Geografi Volume 4 Nomor 1 Januari 2019

atau cendra mata pernak pernik khas pulau Bokori

\section{DAFTAR PUSTAKA}

Muis A. 2016. Peran Dinas Pariwisata Dalam Meningkatkan Kunjungan Wisatawan (Studi Pengembangan Ekowisata Di Kabupaten Penajam Paser Utara).eJournal Administrasi Negara, Volume 4, Nomor 2. Hal. 3991. Diakses 22 maret 2018.www.fisip-unmul.ac.id.

Novita S. 2016. Kepuasan Wisatawan Terhadap Wisata Kuliner Di Objek Wisata Pantai Indah Selatan Baru. eJournal Jom Fisip Vol 3 No.2, hal 5. Diakses 22 desember 2017. http//www.neliti.com

Sugiono. 2014. Metode penelitian kuantitatif, kualitatif dan $R \& D$. Alfabeta : Bandung

Siam.2015. Peranan Dinas Kebudayaan Dan Pariwisata Kabupaten Lingga Dalam Pengembangan Objek Wisata. eJurnal Ipteks Terapan Volume 8 hlm 214 di akses 22 desember 2017

Yoeti.1987. Pengantar Ilmu Pariwisata. Angkasa: Bandung

\author{
Yoeti. 2016. Perencanaan Dan \\ Pengembangan Pariwisata. PT \\ Balai Pustaka. Jakarta.
}

